\title{
COVER-COLLAPSE SINKHOLE DEVELOPMENT IN THE CRETACEOUS EDWARDS LIMESTONE, CENTRAL TEXAS
}

\author{
Brian B. Hunt, P.G., Brian A. Smith, Ph.D., P.G. \\ Barton Springs/Edwards Aquifer Conservation District, 1124 Regal Row, Austin, Texas 78748 USA, \\ brianh@bseacd.org
}

Mark T. Adams, P.G.

ACI Consulting, 1001 MoPac Cir., Ste.100,Austin, Texas 78746 USA, madams@aci-group.net

\section{Scott E. Hiers, P.G.}

City of Austin-Watershed Protection Dept., 505 Barton Springs Rd., Austin, Texas 78704 USA,

Scott.Hiers@austintexas.gov

\section{Nick Brown, P.E.}

Bury+Partners, 221 W. 6th St. \#600, Austin, Texas 78701 USA,nbrown@burypartners.com

\begin{abstract}
Sudden cover-collapse sinkhole (doline) development is uncommon in the karstic Cretaceous-age Edwards limestone of central Texas. This paper presents a casestudy of a sinkhole that formed within a stormwater retention pond (SWRP) in southwest Austin. Results presented include hydrogeologic characterizations, fate of stormwater, and mitigation of the sinkhole.
\end{abstract}

On January 24, 2012, a $11 \mathrm{~cm}$ (4.5 in) rainfall filled the SWRP with about $3 \mathrm{~m}$ (10 ft) of stormwater. Subsequently, a sinkhole formed within the floor of a SWRP measuring

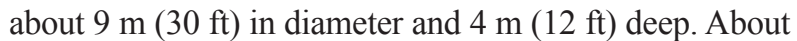
26.5 million liters ( 7 million gallons) of stormwater drained into the aquifer through this opening.

To determine the path, velocity, and destination of stormwater entering the sinkhole a dye trace was conducted. Phloxine B was injected into the sinkhole on February 3, 2012. The dye was detected at one well and arrived at Barton Springs in less than 4 days for a minimum velocity of $2 \mathrm{~km} /$ day $(1.3 \mathrm{mi} /$ day $)$.

Review of pre-development 2-foot topographic contour and geologic maps reveals that the SWRP was built within a broad $\left(5,200 \mathrm{~m}^{2} ; 6\right.$ acre $)$, shallow depression bounded by two inferred NE-trending fault zones. Photographs taken during SWRP construction showed steep west-dipping bedrock in the northern SWRP wall. Following collapse of the sinkhole, additional hydrogeologic characterization included excavation to a depth of $6.4 \mathrm{~m}(21 \mathrm{ft})$, surface geophysics (resistivity), and rock coring. Geologic materials consisted mostly of friable, highly altered, clayey limestone consistent with epikarst in-filled with terra rosa providing a cover of the feature. Dipping beds, and fractured bedrock support proximity to the mapped fault zone. Geophysics and surface observations suggested a lateral pathway for stormwater flow at the junction between the wet pond's impermeable geomembrane and compacted clay liner for the retention pond. The collapse appears to have been caused by stormwater down-washing poorly consolidated sediments from beneath the SWRP and into a pre-existing karst conduit system.

Mitigation of the sinkhole included backfill ranging from boulders to gravel, a geomembrane cover, and reinforced concrete cap. Additional improvements to the SWRP included a new compacted clay liner overlain by a geomembrane liner on the side slopes of the retention pond.

\section{Introduction}

Karst is a terrain with distinctive hydrology resulting from the combination of high rock solubility and welldeveloped solution channel porosity underground (Ford, 2004). Karst terrains and aquifers are characterized by sinking streams, sinkholes, caves, springs, and an integrated system of pipe-like conduits that rapidly transport groundwater from recharge features to springs (White, 1988; Todd and Mays, 2005). Sinkholes (also known as dolines) have long been characteristic of many karstic terrains in many areas of the world (White, 1988; Gunn, 2004). Caves and sinkholes are a very characteristic and common occurrence in the Cretaceousage limestones of Texas in the Edwards Plateau and Balcones Fault Zone (Kastning, 1987). The purpose of 
this paper is to document the development and mitigation of a cover-collapse sinkhole in the Edwards Group limestones. This sinkhole occurred in the Arbor Trails retail development stormwater pond and is referred to as the Arbor Trails Sinkhole (ATS). This case study will lead to insights into how to avoid activating or inducing sinkhole collapse in the future.

\section{Sinkholes}

A broad discussion of sinkholes is beyond the scope of this study, but some introduction to cover-collapse sinkholes is helpful. Sinkholes can be generally defined as "a natural enclosed depression found in karst landscapes" (Williams, 2004). The mechanisms of sinkhole development are often multi-faceted and include dissolution, collapse, suffusion (winnowing or downwashing), and regional subsidence. These mechanisms produce sinkholes described broadly as either a solution sinkhole, or a collapse sinkhole.

A typical limestone sinkhole develops as a depression formed by the slow process of dissolution forming a broad bowl with a gentle slope. Solution sinkholes usually have soil cover and eventually the floor will collapse rapidly due to gravitational forces following continued dissolution, down-washing of soils, and upward stoping of the cavern (void) ceiling. Sudden collapse, due to mechanically weakened unconsolidated (usually clay-rich) sediments, can then down-wash through solution pipes in the bedrock. These covercollapse sinkholes produce steep-sided slopes and are cylindrical in geometry (Williams, 2004). Granular sediments have a different morphology and can form more slowly (Denton, 2013, written communication). Cover-collapse sinkholes generally refers to soil cover, and not collapse of mappable geologic units (Veni, 2012, written communication). Cover-collapse sinkholes are also called dropout dolines, or simply collapse dolines (Williams, 2004; White, 1988).

Development of sinkholes is related to the ability of water to flow through karst rocks and discharge to springs (Williams, 2004). Recharge water dissolves the rock over geologic time, which allows more water to flow, and therefore is a self-reinforcing mechanism speeding up the process. Significant dissolution is thought by some to occur within $9 \mathrm{~m}$ (30 ft) of the surface, leaving behind a highly corroded and permeable zone termed epikarst (Williams, 2004).
The collapse of sinkholes is clearly a natural phenomenon. However, Beck and Sinclair (1986) describe how humans can accelerate the process and "activate" or "induce" a collapse sinkhole. This occurs by increasing the infiltration of water, which speeds up the piping of unconsolidated materials, creating a large void and caves in the soil or regolith, resulting in collapse.

Sinkhole development in the karstic areas of Texas is a common occurrence and is documented in Kastning (1987), but cover-collapse sinkholes are uncommon. Many studies of the eastern United States document cover-collapse sinkholes leading to structural or other environmental problems (Newton and Tanner, 1987). However, the authors are not aware of any sudden covercollapse of sinkholes resulting in significant structural damage in the karstic Edwards, although examples may exist in areas with thick soils. Instead, the Edwards has many relatively stable sinkholes that do not cause major structural problems due to collapse. These stable collapse sinkholes are more accurately described as cave-collapse, or bedrock-collapse, sinkholes related to the intersection of older phreatically-formed caves with the land surface due to erosion of the overlying strata. Other stable sinkholes are formed by more recent vadose dissolution (often with a combination of collapse) and are directly linked to the current surface hydrology.

The absence of sudden cover-collapse sinkholes in the Edwards Group is due primarily to the lack of thick soil cover throughout central Texas as the karst bedrock is often exposed directly at the surface. Other factors include the semi-arid climate and the deep water table conditions.

\section{Setting}

The Edwards Aquifer system lies within the Mioceneage Balcones Fault Zone (BFZ) of south-central Texas and consists of an area of about $10,800 \mathrm{~km}^{2}\left(4,200 \mathrm{mi}^{2}\right)$. Groundwater from the Edwards Aquifer is the primary source of water for about two million people, plus numerous industrial, commercial, and irrigation users. The Edwards Aquifer system also supports 11 threatened or endangered species, aquatic habitats in rivers of the Gulf Coastal Plain, and coastal bays and estuaries. Hydrologic divides separate the Edwards Aquifer into three segments. North of the Colorado River is the Northern segment, and south of the southern hydrologic divide near the City of Kyle is the San Antonio segment (Figure 1). The Barton Springs segment is located between 
these two larger segments. The Shops at Arbor Trails is the development where the subject sinkhole developed, and is located within the recharge zone of the Barton Springs segment of the Edwards Aquifer (Figure 1).

Development of the Edwards Aquifer was influenced significantly by fracturing and faulting associated with Miocene-age tectonic activity and subsequent dissolution of limestone and dolomite units by infiltrating meteoric water (Sharp, 1990; Barker et al., 1994; Hovorka et al., 1995; Hovorka et al., 1998; Small et al., 1996). Development of the aquifer is also thought to have been influenced by deep dissolution processes along the saline-fresh water interface, what is known as hypogene speleogenesis (Klimchouk, 2007; Schindel et al., 2008).

The majority of recharge to the aquifer is derived from major stream channels originating on the contributing zone, located upgradient and primarily west of the recharge zone. Water flowing onto the recharge zone sinks into numerous caves, sinkholes, and fractures along numerous (ephemeral to intermittent) losing streams. For the Barton Springs segment, Slade et al. (1986) estimated that as much as $85 \%$ of recharge to the aquifer is from

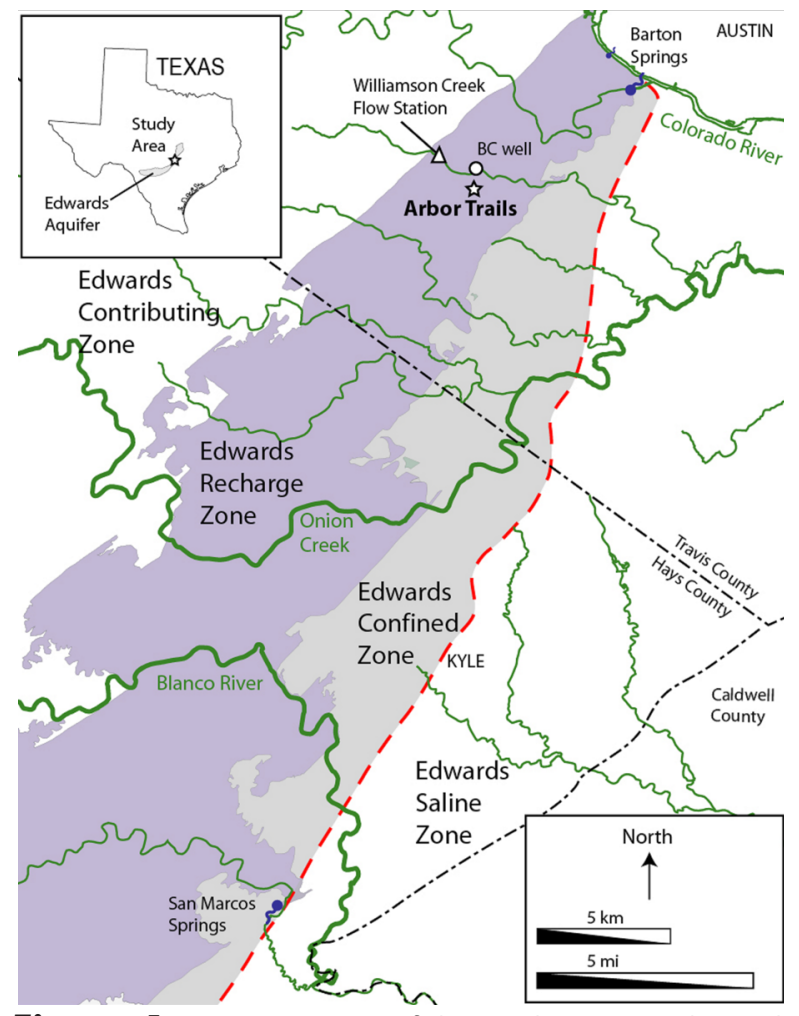

Figure 1. Location map of the study area. Indicated are the Brush Country well (BC well) and a USGS stream gage station on Williamson Creek. water flowing in these streams. The remaining recharge $(15 \%)$ occurs as infiltration through soils or direct flow into recharge features in the upland areas of the recharge zone (Slade et al., 1986). More recent water balance estimates of the Barton Springs segment suggest that more water could be recharged in the upland or intervening areas (Hauwert, 2009; Hauwert, 2011; Hauwert, 2012).

The Edwards Aquifer is inherently heterogeneous and anisotropic, characteristics that strongly influence groundwater flow and storage (Slade et al., 1985; Maclay and Small, 1986; Hovorka et al., 1996 and 1998; Hunt et al., 2005). The Edwards Aquifer can be described as a triple porosity and permeability system consisting of matrix, fracture, and conduit porosity (Hovorka et al., 1995; Halihan et al., 2000; Lindgren et al., 2004) reflecting an interaction between rock properties, structural history, and hydrologic evolution (Lindgren et al., 2004). In the Barton Springs segment groundwater generally flows from west to east across the recharge zone, converging with preferential groundwater flow paths subparallel to major faulting, and then flowing north toward Barton Springs.

Numerous tracer tests have been performed on portions of the Edwards Aquifer demonstrating that rapid groundwater flow occurs in an integrated network of conduits discharging at wells and springs (BSEACD, 2003; Hauwert et al., 2004; Johnson et al., 2012). In the Barton Springs segment these flow paths are parallel to the N40E (dominant) and N45W (secondary) fault and fracture trends presented on geologic maps, indicating the structural influence on groundwater flow. Rates of groundwater flow along preferential flow paths, determined from dye tracing, can be as fast as 11.3 $\mathrm{km} /$ day (7 mi/day) under high-flow conditions or about 1.6 $\mathrm{km} /$ day (1 mi/day) under low-flow conditions (Hauwert et al., 2002).

\section{Arbor Trails Pre-Development Site Characterization and Planning}

The $0.3 \mathrm{~km}^{2}$ (72-acre) property was developed in accordance with City of Austin's Land Development Code and the State of Texas requirements (Chapter 213 Edwards Rules). These requirements include geologic and environmental assessments, and reduction of pollution in stormwater leaving the site. The City of Austin has the most stringent requirements (so called "SOS Ordinance") that limit impervious cover and set nondegradation standards for the treatment of stormwater 
on the Edwards Aquifer recharge zone. To achieve this standard, a variety of water quality measures, including construction of Storm Water Retention Ponds (SWRP) are required for development sites. Within the Edwards Aquifer recharge zone SWRPs are a type of permanent water-quality control designed to capture stormwater runoff and sediment so that sediments and other contaminants are not carried further downstream or into the Edwards Aquifer. The failure of a SWRP permits sediment and contaminated stormwater to leave a site and likely enter the aquifer.

Both the State and the City permitting processes stipulate that a karst survey be completed to identify and evaluate all karst recharge features. In addition to the State permitting, the City requires an environmental assessment that identifies any critical environmental features such as karst recharge features, springs, and wetlands. From 1994 to 2006, several development permit applications were submitted for the study property resulting in numerous environmental and geologic assessments. Beside the completion of an site-specific environmental and geologic assessments provided in 1994 and 2004, respectively, at least two phase one environmental assessments were prepared to address hazardous material and general environmental concerns (Kleinfelder, 2005).

In 2004 a karst survey and geologic assessment was completed by HBC/Terracon (2004). The geologic assessment identified three small and minor solution and depression features (S1-S3) in the northeast portion of the property and also identified one mapped fault zone on the property (Figure 2). The fault zone and the geologic units are consistent with the geologic map of Small et al., 1996. The

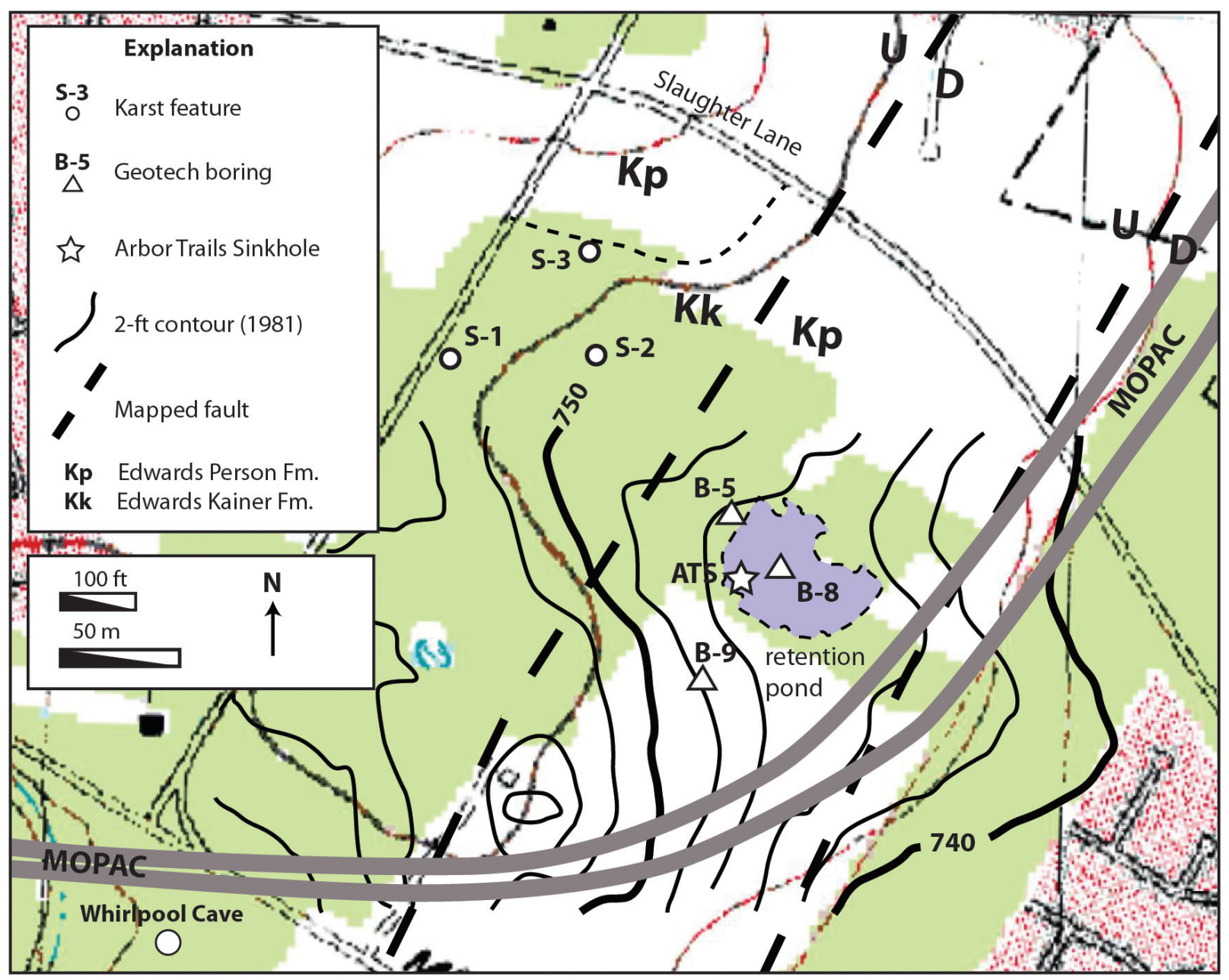

Figure 2. Predevelopment topographic map. Basemap is USGS Oak Hill Quadrangle (10-ft contours in brown). Geologic information from HBC/Terracon (2004). Geologic units and faults are consistent with Small et al., 1996. Black lines are City of Austin 2-ft topographic contours dated 1981, prior to major highway (MoPac). Contours create a depression centered around the SWRP (shown as dashed lines). 
three features were evaluated and scored as sensitive (i.e., they could be pathways for contamination) in the report, but were not considered significant recharge features since they had a small surface catchment area. The fault zone had no surface expression observed and was located based upon published maps (Small et al., 1996). The fault was not scored in the report (HBC/Terracon, 2004) as it was inferred from the map alone. The geologic assessment concluded that, "Due to the lack of any significant recharge features observed on the site, the potential for fluid movement to the Edwards Aquifer beneath the site is considered very low" (HBC/Terracon, 2004).

As part of the site permitting processes, City staff evaluated the findings of these assessments and conducted follow-up field verification of karst and critical environmental features described in the reports. This resulted in an additional karst survey by City staff. None of the assessments or followup site verification investigations identified significant recharge features on the study site, or a large depression in the vicinity of the ATS. City staff were not notified of any subsurface voids encountered during construction.

Review of topographic contours from the City of Austin 2-ft contour maps dated 1981 prior to MoPac (Loop 1) reveals a very shallow and large $\left(5,200 \mathrm{~m}^{2} ; 6\right.$ acre) depression centered on the SWRP (Figure 2). The contours agree with an even more subtle depression on the 10-ft contour USGS Quadrangle Map. The area appears well drained from the aerial as no ponded features are evident, and hardwood trees are present. However, the subdued nature of the feature and the subsequent disturbance from the highway that bisected the eastern portion of the depression would make detection of the feature in the field difficult.

As part of the site engineering studies, geotechnical cores and borings were conducted throughout the site. Preliminary geotechnical studies include $6 \mathrm{~m}$ (20-ft) deep cores that were collected near the ATS (B-8 and B-9; Figure 2). The bores extended the same depth as the final SWRP excavation depth. Both cores returned rock quality designation (RQD) of very poor to incompetent rock. Both cores indicated loss of fluids within the first $3 \mathrm{~m}$ (10 feet) and solution channels and small voids (HBC/Terracon, 2005), consistent with epikarst.

The location of the SWRP for the Arbor Trails development is shown in Figure 3. The purpose of the
SWRP is to capture storm runoff from impervious areas (buildings and parking lots) and then irrigate vegetative areas with the stormwater throughout the property. The SWRP consists of two water quality controls; a geomembrane-lined wet pond inset within a compacted clay-lined retention pond. The wet pond has a forebay and main permanent pool area that are separated by a berm. The wet pond was constructed for aesthetics within the retention basin. The retention pond has its capture volume above permanent pool elevation for the wet pond. The capture volume for the retention pond extends up $1.8 \mathrm{~m}(6 \mathrm{ft})$ onto the slope areas of the basin. The retention pond is the actual permitted waterquality control structure for the surrounding shopping center. During a rain event stormwater captured by the retention basin is held and then irrigated on vegetated areas throughout the property within 72-hours.

\section{Hydrologic Conditions and Sinkhole Collapse}

Prior to collapse of the ATS, central Texas had been experiencing a severe drought. Beginning in late January, rainfall and subsequent recharge brought the aquifer out of drought conditions.

On January 24, 2012, an $11 \mathrm{~cm}$ (4.5 in) rainfall event occurred in the area of the Arbor Trails development filling the SWRP with about $3 \mathrm{~m}(10 \mathrm{ft})$ of water (Figure 4). On January 25, 2012, maintenance crews noticed the pond was draining, and that a sinkhole had developed (Figure 5). The size of the sinkhole was about $9 \mathrm{~m} \mathrm{(30}$ $\mathrm{ft})$ in diameter and $4 \mathrm{~m}$ (12 ft) deep. About 26.5 million liters ( 7 million gallons) of storm water drained into the aquifer through this opening.

A significant increase in turbidity at Barton Springs is associated with the late January (and March) rainfall. These types of increases are relatively common in this karst system. Barton Springs/Edwards Aquifer Conservation District (District) staff observed the runoff and recharge into swallets (Brodie Cave) within nearby tributaries of Slaughter Creek from the same rainfall event that created the ATS. It was noted that the stormwater entering those features was very turbid. Accordingly, the jump in turbidity cannot be attributed to the failure of the SWRP.

\section{Sinkhole Characterization Studies}

Following the collapse, the sinkhole was further characterized by excavation, surface geophysics, and 


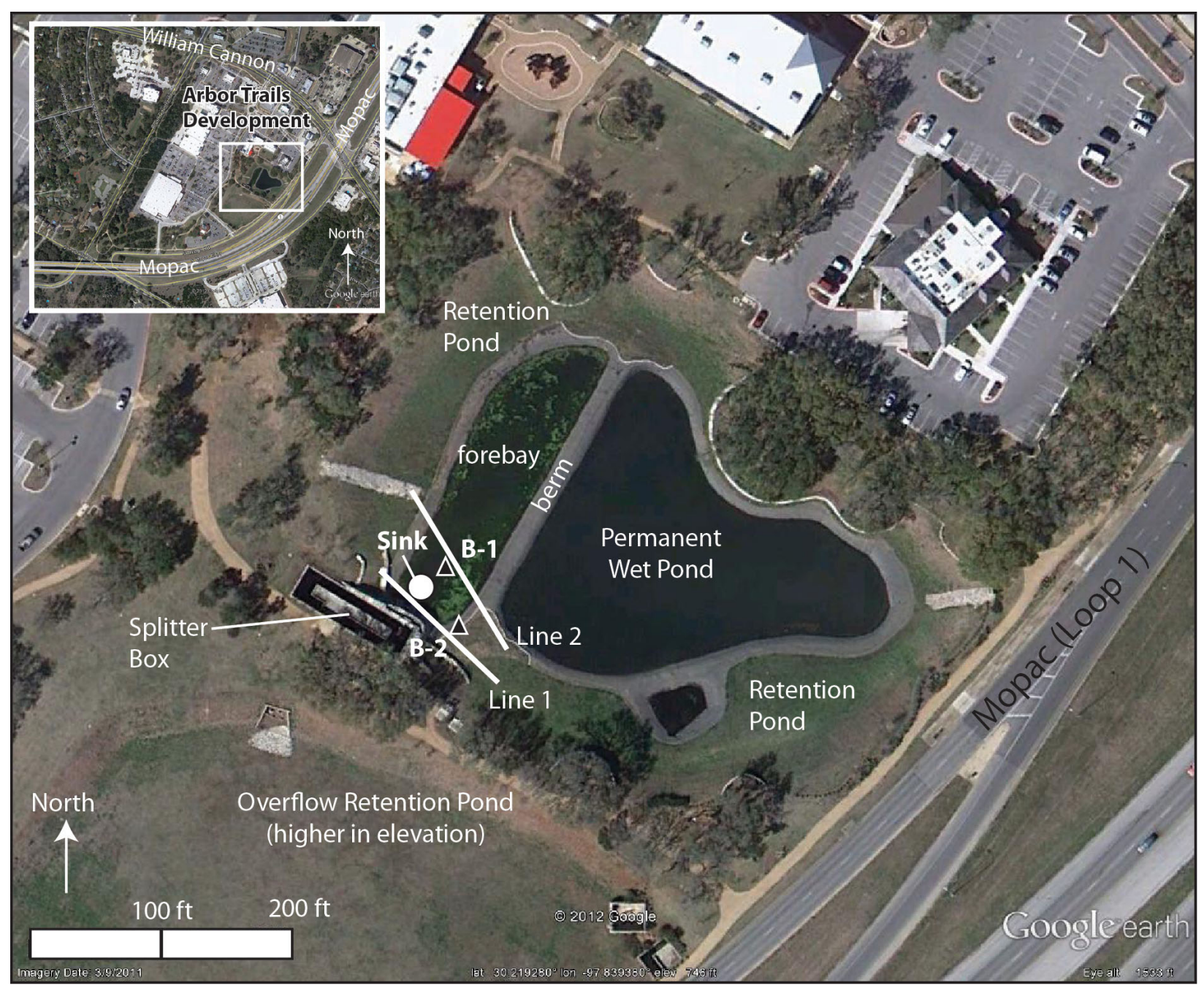

Figure 3. Detailed site map with key elements of the stormwater retention pond (SWRP), sinkhole location, and 2012 geophysical lines and boreholes.
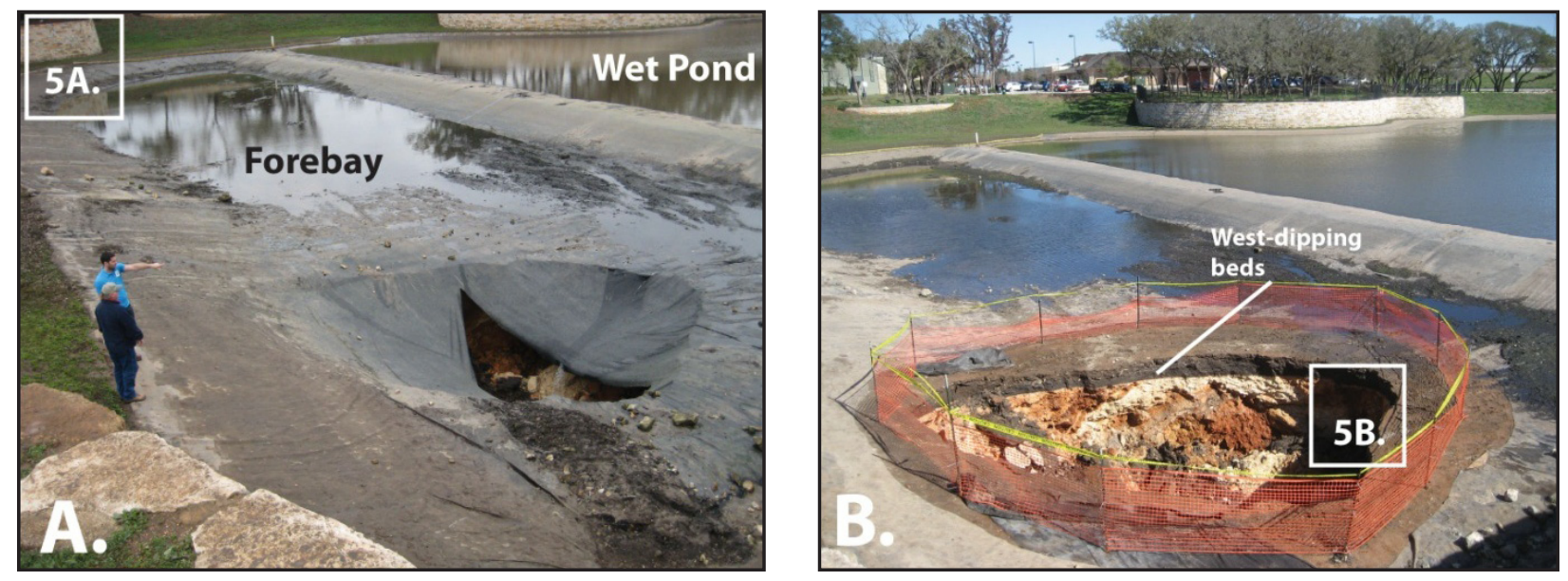

Figure 4. Photograph of sinkhole, all photos facing north. A) photo taken the day the sinkhole was observed (credit Heather Beatty, TCEQ).

B) Photo taken two days after collapse and prior to excavation. Note the limestone beds are dipping to the west. 

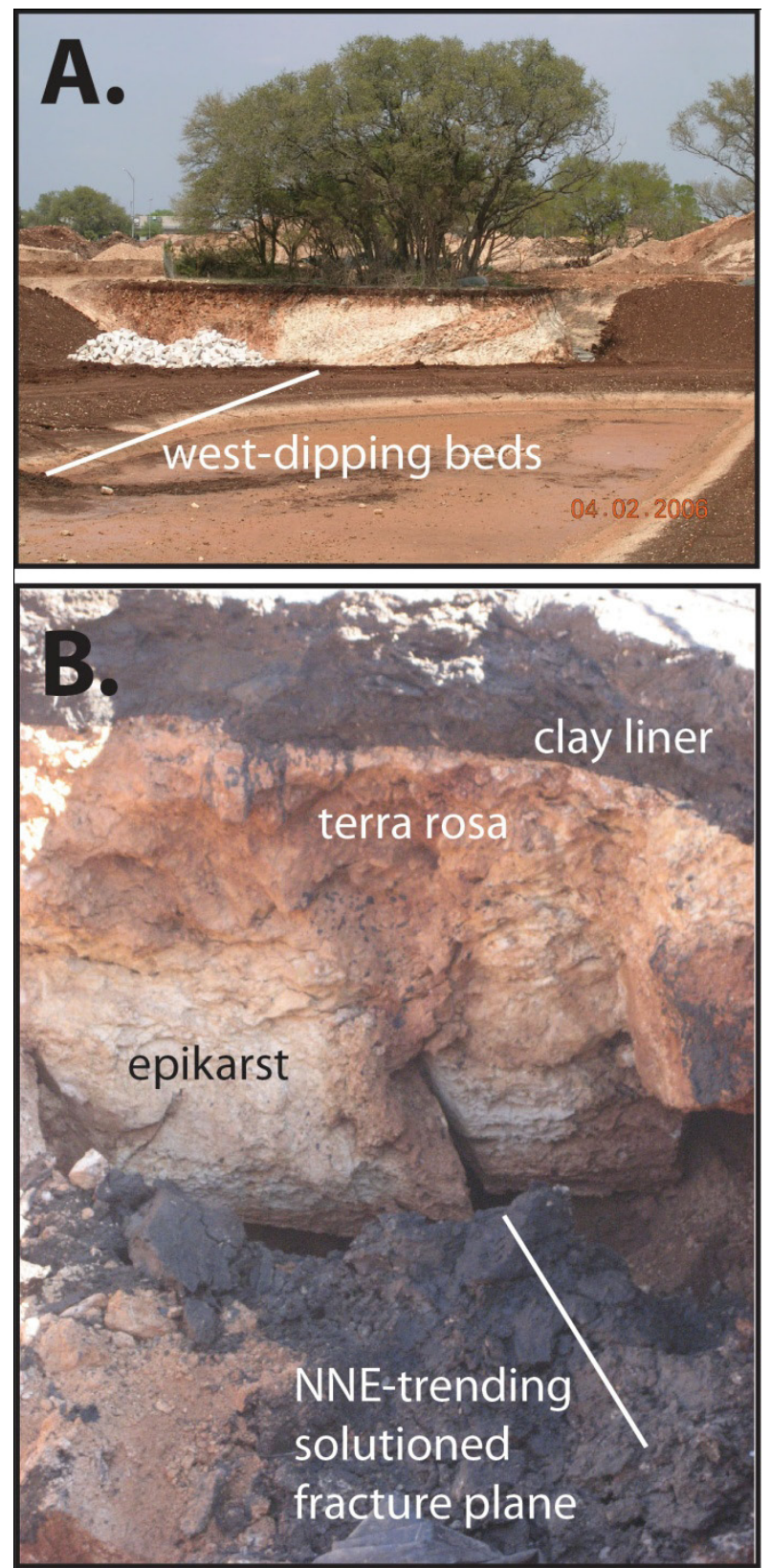

Figure 5. Photograph locations indicated in Figure 4. A) Photo during construction of SWRP showing west-dipping beds in the northern wall of the forebay (photo credit Andrew Backus, 4/2/2006); B) Photo of the northern wall of the sinkhole taken two days after collapse and prior to excavation.

borehole (core) drilling by ACI Consulting (Austin, Texas). Prior to those studies the District and City of Austin $(\mathrm{CoA})$ conducted the dye tracing studies. The ATS was excavated to a total depth of $6.4 \mathrm{~m}(21 \mathrm{ft})$ (Figure 6). Most of the excavated geologic material in the sinkhole consisted of friable, highly altered (weathered), clayey limestone fragments consistent

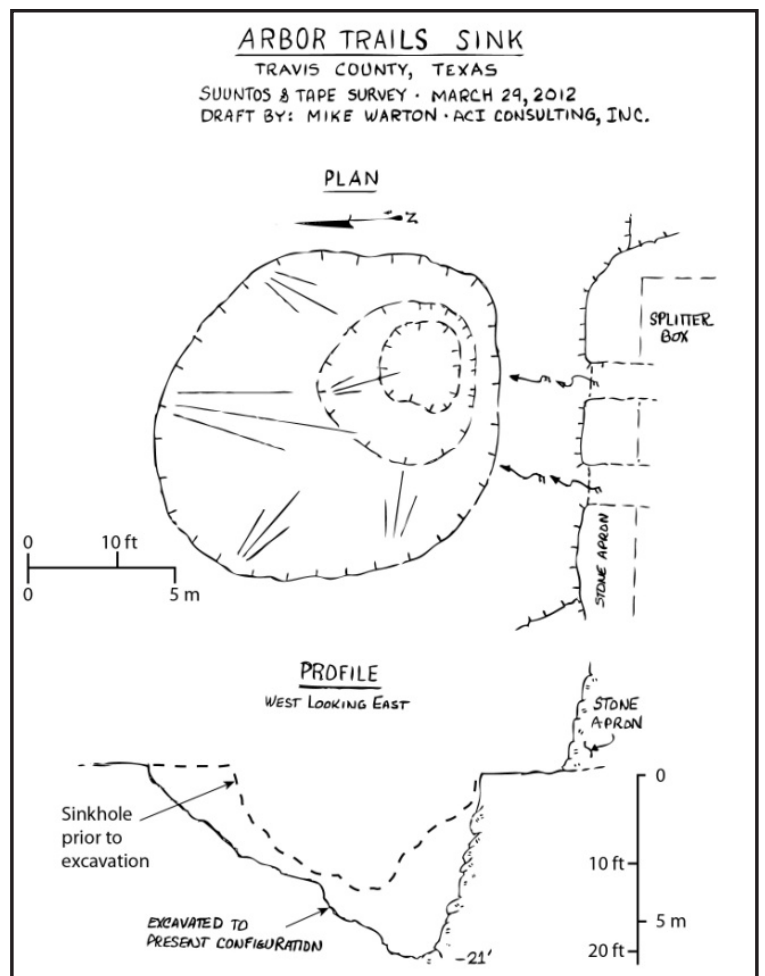

Figure 6. Sketch of sinkhole after excavation (by Mike Warton of $\mathrm{ACl}$ Consulting).

with terra rosa and regolith filling the epikarst zone. Very little competent bedrock was encountered in the excavations. Solution fractures striking to the north, and west- dipping limestone beds in the sinkhole and in the northern retaining wall, were observed (Figure 5). Geotechnical and geologic information of the bedrock adjacent and within the ATS reveal highly fractured and steeply dipping bedrock suggesting the ATS developed proximal to a fault zone.

\section{Geophysics}

The nature of collapse suggested the possible existence of a significant subsurface void allowing the structurally unstable material to further collapse into a void of unknown dimensions. To assess the void and assure structural stability for equipment and workers safety, a mechanism for subsurface evaluation was needed. Based on an initial review of the collapse, ACI proposed a geophysical approach. ACI uses geophysics on numerous karst features and the findings are validated by geotechnical borings and subsequent construction activities. In conjunction with the client and the regulatory authorities, a geophysical electrical resistivity array was designed in conjunction with Round Rock Geophysics Inc. (Round Rock, Texas) to evaluate the shallow surface for anomalies and take a deeper look at the subsurface. 
Six arrays (4 E-W, 2 N-S) were conducted to evaluate conditions near the void and assess the surrounding area. The second bay (permanent pool) of the pond was not accessible as it was being used as a backup water quality control for development. For the array, metal spikes were driven into the ground to a depth of $20 \mathrm{~cm}$ ( 8 in) at a separation distance that is predetermined based on desired resolution and survey depth. As this investigation was designed to evaluate the subsurface for the collapse geometry and to assure worker safety, a moderate spacing was chosen. Probe spacing on lines 1 and 2 was $1.5 \mathrm{~m}$ (5 ft), which allowed for moderate penetration depth $(18 \mathrm{~m}, 60$ $\mathrm{ft}$ ) and a resolution on the order of one meter $(3 \mathrm{ft})$. Other survey lines had spacing on the order of $2.1 \mathrm{~m}$ $(7 \mathrm{ft})$, reducing resolution, but increasing the depth to over $24 \mathrm{~m}(80 \mathrm{ft})$. Each probe is connected to an electrical control, data recorder, and a 12-volt battery. Each probe alternated acting as an electrical source and receiver. The electrical pulses were recorded and the electrical energy loss recorded and the results are illustrated in Figure 7.

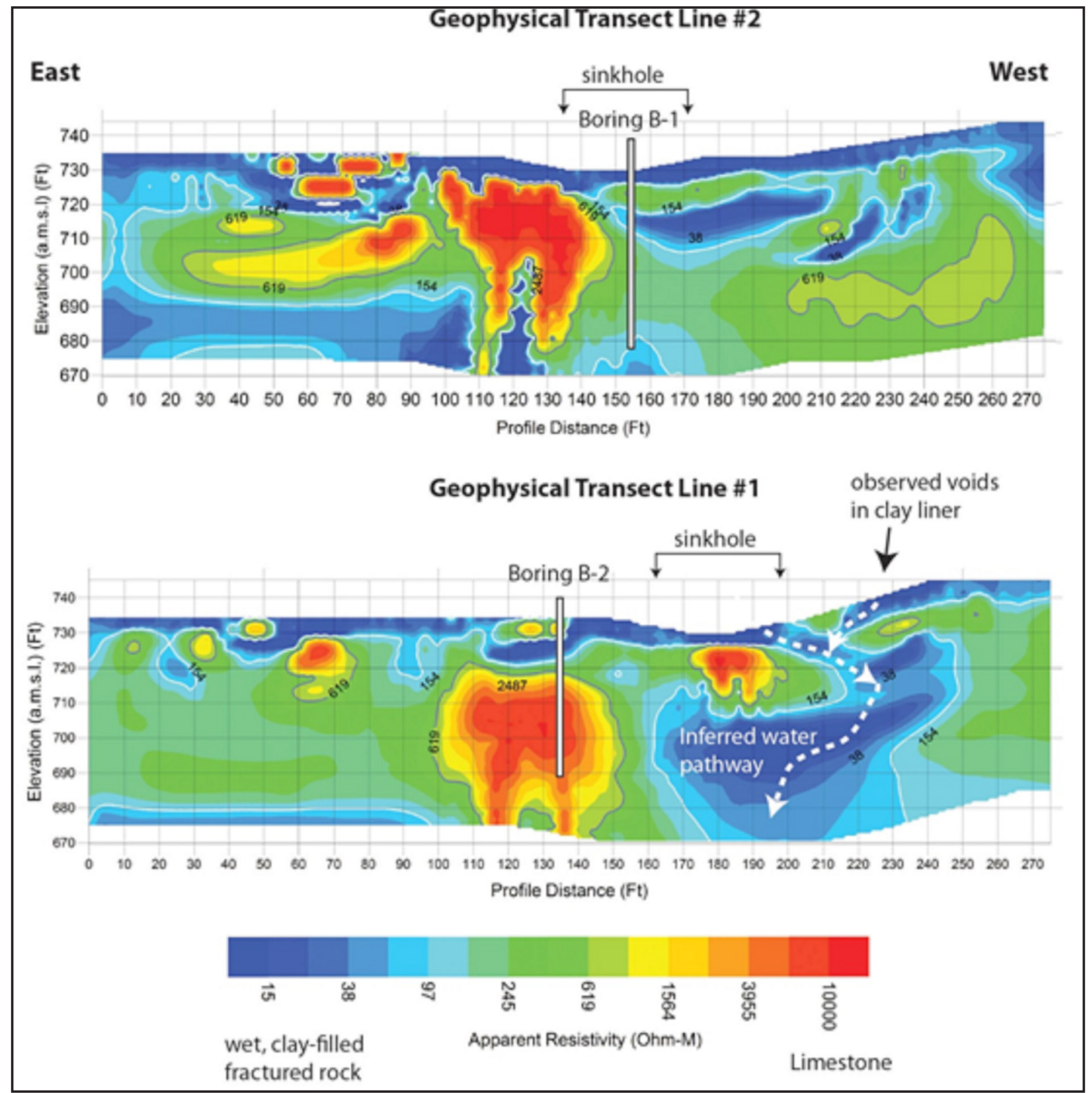

Figure 7. Resistivity profile from lines 1 and 2 (shown on Figure 3). The sinkhole was located between these two lines. Note the interpretation of water infiltration. This is based upon the resistivity data and the voids observed in the compacted clay material of the retention pond. 
Since "resistivity" is a relative measure, two geotechnical borings (B-1 and B-2) were drilled adjacent to the sinkhole to physically evaluate the subsurface and calibrate the geophysical model. Based on the borings, warmer (red) colors representing higher resistivity were determined to be relatively competent (crystalline) limestone. Cooler blue colors representing lower resistivity (high conductivity) were determined from Boring 1 to be wet to saturated clay-filled fractured rock. Boring 2 had poor recovery also suggesting highly fractured rock.

\section{Activation of Collapse}

Small voids observed in the compacted clay liner of the retention pond adjacent to the sinkhole, and in the western side of the SWRP, suggest the most likely pathway for water was around the geomembrane liner. These field observations along with the geophysics and other data suggest that water from the SWRP was bypassing the impermeable synthetic liner and infiltrating through the compacted clay liner (Figure 7). The infiltrating water is thought to have flowed within the observed wet and saturated clay-filled rock below the voids in the clay liner. Other interpretations of pathways beneath the liner are possible. Ultimately the infiltrating water carried the finer interstitial clays and sediment into underlying voids. The down-washing created shallower voids and along with a significant hydrostatic load of the ponded stormwater, resulted in a collapse of the relatively weak cover material and development of the sinkhole.

\section{Sinkhole Recharge and Groundwater Flow}

Dye-trace studies are an effective means to determine the path, velocity, and destination of groundwater in a karst setting. A dye trace was performed to better understand flow in the area and test which groundwater basin and, therefore springshed, the ATS was developed within. The results will help scientists understand the fate of the stormwater in the ATS, and also how future contaminant spills along MoPac, a major highway adjacent to the study site, will move.

A dye-trace study was conducted in the ATS by the District and the CoA. District staff injected $7.4 \mathrm{~kg}$ (16.3 lbs) of Phloxine B dye into the sinkhole on February 3, 2012 (Figure 8). The dye was detected at one well and Barton Springs with a minimum velocity of $2.1 \mathrm{~km} /$ day ( $1.3 \mathrm{mi} /$ day). Results of the trace confirms that the ATS is within the Sunset Valley groundwater basin as previously defined by Hauwert et al. (2004) (Figure 9). Similar to

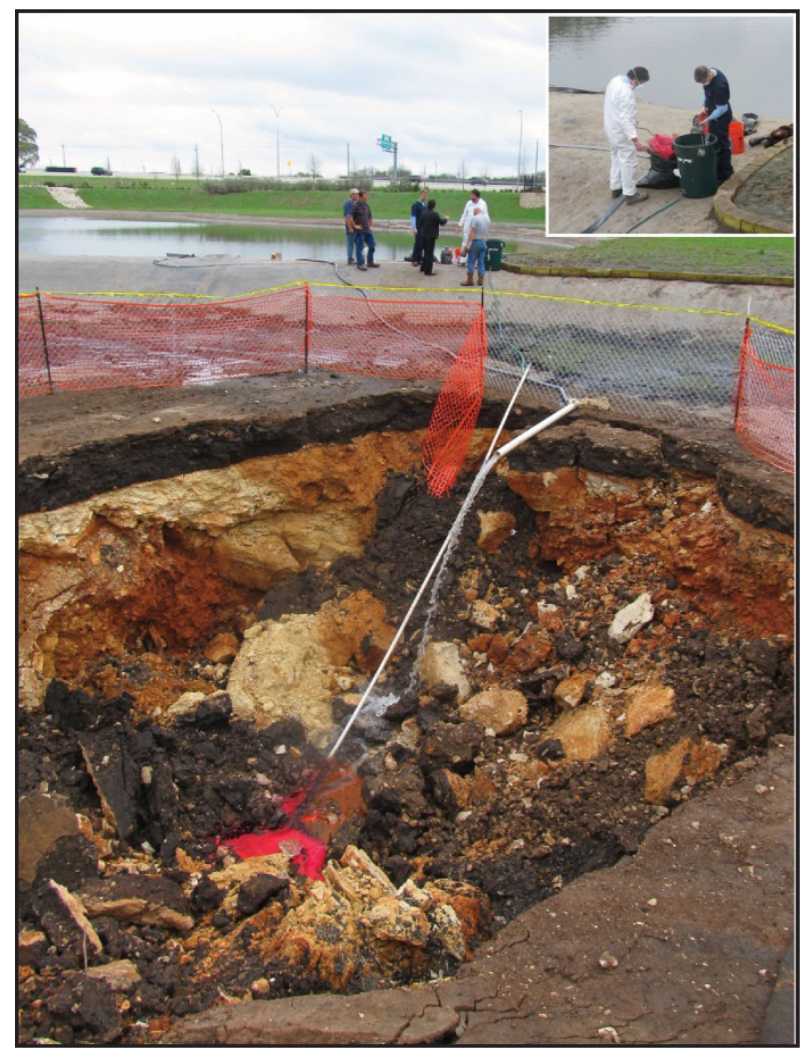

Figure 8. Phloxine $B$ dye injection at Arbor Trails sinkhole. Dye was injected on February 3, 2012. A mass of about $7 \mathrm{~kg}(16 \mathrm{lbs})$ was mixed in a trash can and then gravity injected via a hose and polyvinyl chloride (PVC) pipe using water from an adjacent wet pond.

so many karstic features in the area, the results indicate that the sinkhole is well-integrated into the karstic conduit system of the aquifer.

\section{Sinkhole Mitigation and SWRP Improvements}

An engineered closure design by Bury + Partners (Austin, Texas) was reviewed and approved by the City and State to mitigate the sinkhole. The plan consisted of graded fill interlayered with filter fabric (Figure 10). Large rock ( $>15 \mathrm{~cm},>6$ inch) filled the base and was overlain by $7-12 \mathrm{~cm}$ (3-5 in) gravel, then overlain by 3-8 cm (1-3 in) gravel, and capped with $3 \mathrm{~cm}$ (1 in) gravel. A vapor barrier lined the top of the gravel and a reinforced concrete slab was poured on the top and anchored into the splitter box. A compacted clay liner was installed over the concrete followed by a geomembrane liner, both of which covered the entire SWRP (Figure 11).

In addition to the closure of the sink, the owners of the site made significant improvements to the entire SWRP 


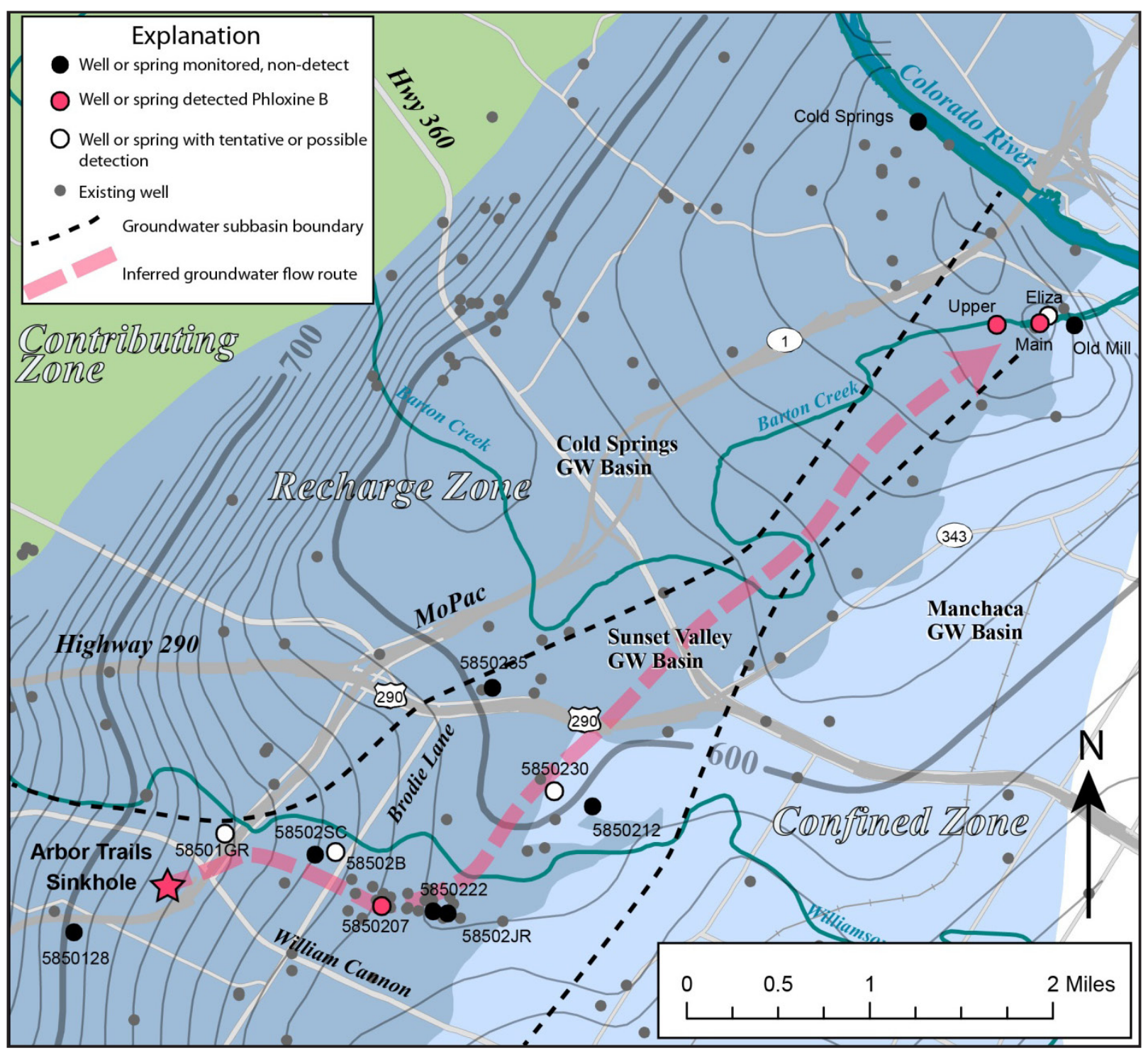

Figure 9. Map of results from the Arbor Trails dye trace. Pink circles indicate positive detections (very high confidence, both labs) of Phloxine B. White circles are wells with tentative detections (single detections from EAA lab), and solid black circles are locations with non-detects (both labs). Dashed pink line represents estimated flow route and is coincident with the "Sunset Valley Flow Route" defined by Hauwert et al., 2004. Small gray circles are existing water-supply wells. Light gray potentiometric lines are from February 2002 high flow conditions (10-ft contour intervals). Groundwater basins are defined in Hauwert et al., 2004.

to prevent future leakage and sinkhole development (Figure 11). Existing geomembrane liner was replaced and extended $30 \mathrm{~cm}(1 \mathrm{ft})$ above the maximum water level of the retention pond (previously the liner only existed for the wet pond). The subgrade underneath the geomembrane liner within the retention pond was replaced with new high quality compacted clay liner and $0.3 \mathrm{~m}(1 \mathrm{ft})$ protective soil and grass cover installed over geomembrane line. All masonry walls in the SWRP were grouted and sealed to prevent leakage.

\section{Discussion}

Figure 12 illustrates a conceptual hydrogeologic model of the cover-collapse sinkhole at the AST. A broad shallow depression is indicative of a solution sinkhole (Figures 2 and 12A). Evidence of a fault zone include fractures and dipping beds at the site (Figures 4 and 5). Geotechnical borings revealed highly fractured and altered epikarst rock within the SWRP. The SWRP removed about 6 m (20 ft) thick horizon of terra rosa-filled epikarst that likely acted as a mantle of poorly consolidated material 


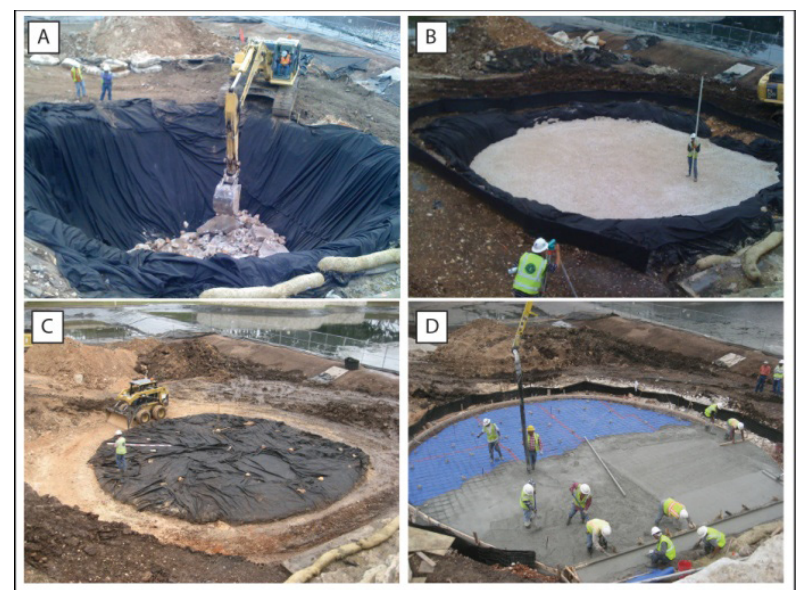

Figure 10. Photographs during sinkhole mitigation. A) Boulders and coarse fill and filter fabric; 5/2/12, B) graded cobble to gravel fill; 5/7/12, C) Gravelfilled sinkhole and filter fabric; 5/9/12, D) Reinforced concrete cap and blue vapor barrier; 5/10/12.

over a fractured and dissolved karstic fault zone (Figure 12B). Hydrostatic loading and stormwater flow around the geomembrane liner and through the epikarst zone allowed down-washing of sediments along solution pipes (Figure 5), and upwards stoping of the void ceiling at depth. Sudden failure occurred as mechanically weak sediments were down-washed through solution pipes in the bedrock (Figures 5 and 12C). Dye tracing established the sinkhole is well-integrated into the aquifer conduit system (Figure 9). The sinkhole was mitigated with graded fill, geomembranes, and a concrete slab. Improvements to the SWRP included extending the liner above the high-water elevation (Figures 11 and 12D).

Under the current development process it is unlikely that the regulators or developers of the area in which the sinkhole occurred would have recognized the risk associated with the location of the SWRP, or predicted the failure. Only after compiling all the information does it become clear that human activities (placement of the SWRP on the sinkhole) activated the sinkhole collapse. Part of the challenge is that the land development process in the karstic Edwards Aquifer has inherent problems of communication between geologists, engineers, consultants, and owners over the life of a project. For example, sites are fully designed and engineered, and then the geologic assessment occurs, resulting in little flexibility in site planning. Likely the SWRP was located precisely in the lowest portion of the property, which makes sense from a engineering standpoint. But in this case the low elevation was a
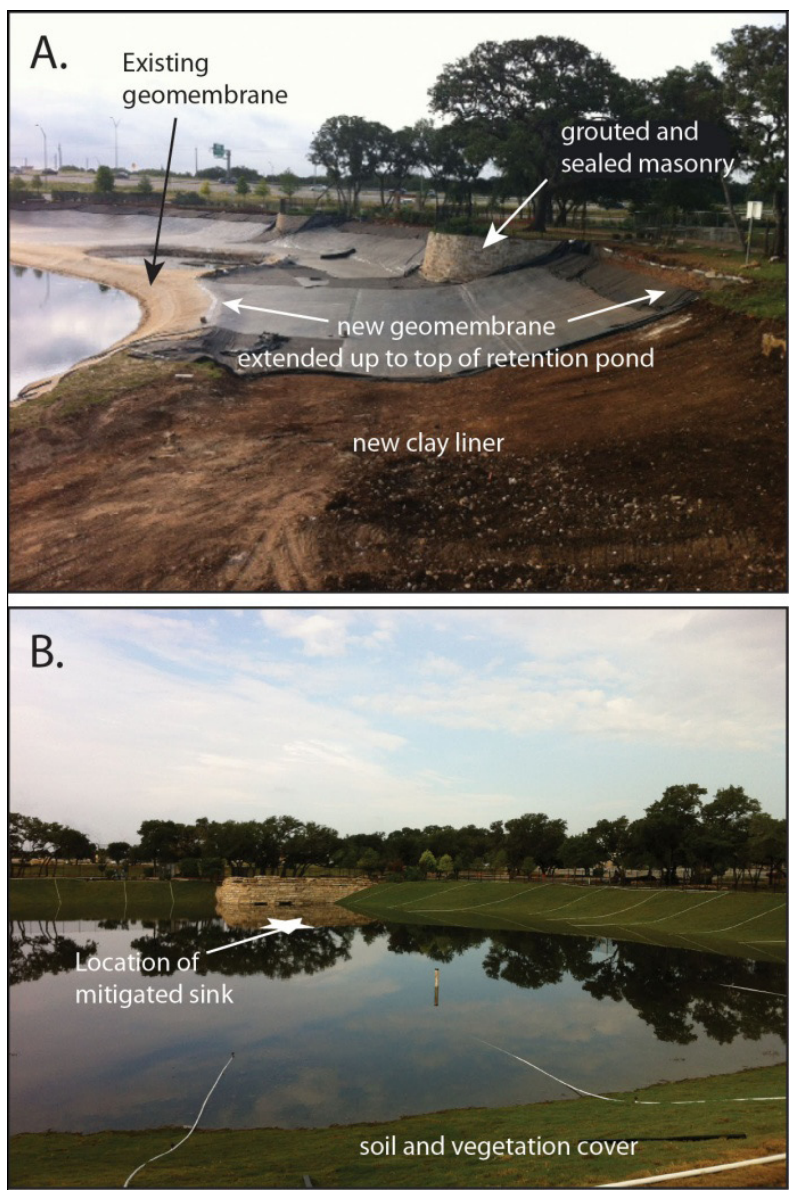

Figure 11. A) Looking east from the splitter box showing new compacted clay liner overlain by new geomembrane. B) Looking south at the stone splitter box and the finished SWRP after significant rainfall event. New soil and vegetation cover in place over geomembrane in SWRP; 7/1 1/12. Note the sinkhole was located in front of the splitter box.

covered sinkhole. In addition, geotechnical studies occur without the input from geologists surveying for karst features. Finally, geologists are not required to inspect the SWRP excavation during its construction. Despite these problems inherent in the development process, the studies and site remediation were a model of communication, transparency, and cooperation among the various regulators, scientists, engineers, and owners. All of these parties have a goal to understand the problem and provide the best solution.

\section{Conclusions}

This case study documents that cover-collapse sinkholes can develop in the central Texas Cretaceous karst system. In this case the cover is a thick horizon of terra rosa infilling of a shallow epikarst zone. In addition, this 
A) Solution Sinkhole: Pre-development

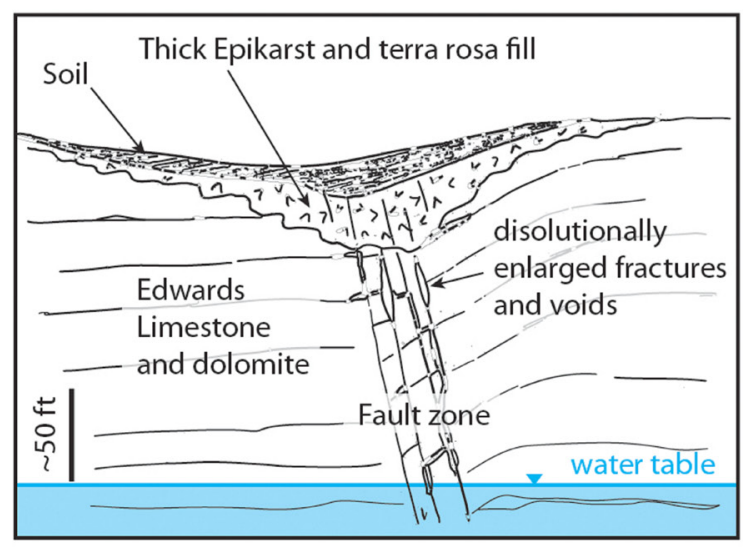

C) Cover-collapse Sinkhole

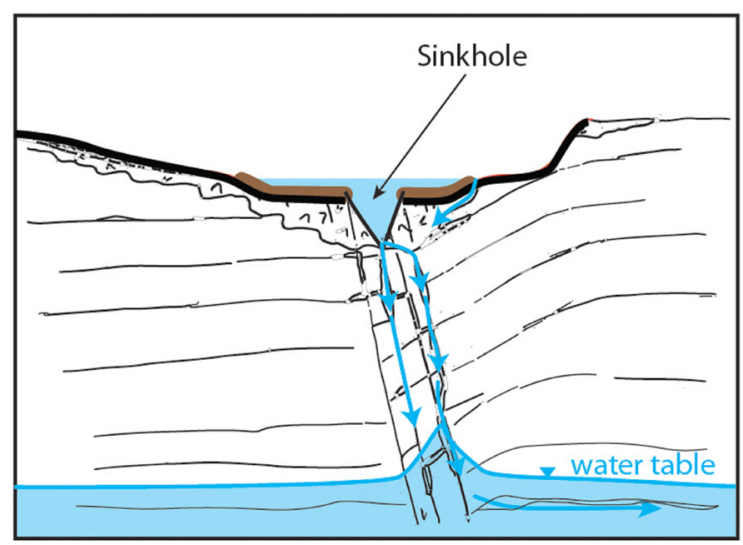

B) SWRP and Sinkhole Activation

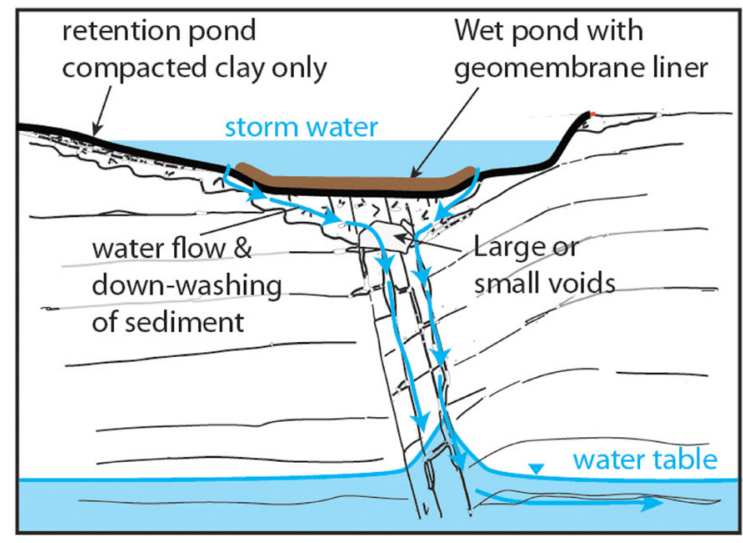

D) Mitigation

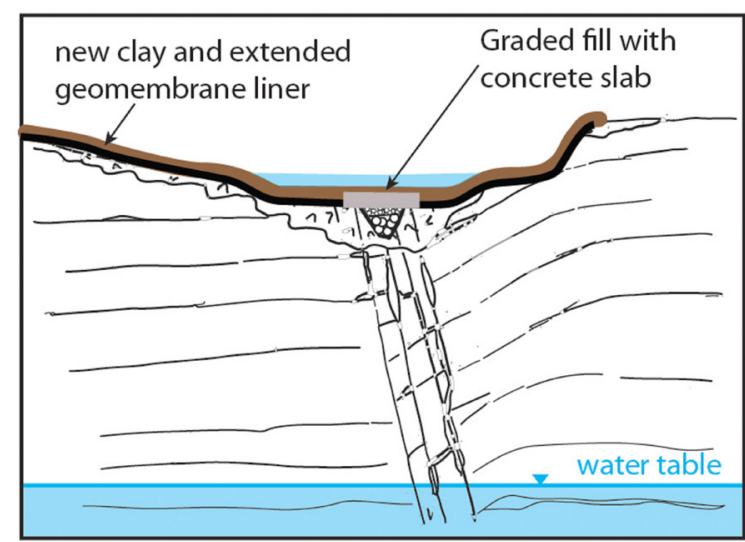

Figure 12. Conceptual hydrogeologic model of sinkhole in four stages: A) Pre-SWRP development, B) SWRP and sinkhole activation, C) cover-collapse, and D) mitigation.

study confirms how human activities, superimposed upon natural karst features, can activate a sinkhole collapse. Dye tracing revealed how wellconnected these features can be with the aquifer system. However, these types of occurrences can be avoided if geologists and engineers are aware of the potential risks associated with SWRPs initiating sinkhole collapse. To reduce the risk of future SWRP failures, studies should be performed beyond current standards for areas impounding water, such as an SWRP. Additional studies could include detailed mapping, topographic surveys, traditional karst surveys, geophysics, and additional geotechnical borings (extending below the final grade) focused around a potential location of an SWRP. Excavations should be inspected periodically by geoscientists and engineers during construction looking for features that could contribute to sinkhole initiation.

\section{Acknowledgments}

This study would not have been possible without the full support of the property owner of the Arbor Trails retail development Mr. Greg Christopher, President of Christopher Commercial Inc. (CCI). We would also like to thank the CCI executive team of Vice President and General Counsel Dan Myrick, Construction and Maintenance Manager Dan Manchiela, and SWRP project manager Chuck Meehan.

We would like to extend our thanks to the Edwards Aquifer Authority (EAA) and especially Geary Schindel and Steve Johnson for their support of the dye tracing portion of this study. The EAA provided Phloxine B dye and also performed the majority of the dye trace analyses. District staff John Dupnik, P.G., Kendall BellEnders, and Robin Gary provided logistical support for the dye tracing portion of this study. Justin Camp (CoA) helped sample the springs as part of the dye trace study. 
We would like to further thank the careful reviews and suggestions that improved this paper by Robert K. Denton, Jr., John M. Caccese, and Tony L. Cooley.

\section{References}

Barker RA, Bush PW, Baker ET Jr. 1994. Geologic history and hydrogeologic setting of the EdwardsTrinity Aquifer System, West-Central Texas. US Geological Survey Water-Resource Investigations Report 94-4039.

Beck B, Sinclair WC. 1986. Sinkholes in Florida: An introduction. Florida Sinkhole Research Institute Report 85-86-4.

BSEACD. 2003. Summary of groundwater dye tracing studies (1996-2002), Barton Springs segment of the Edwards Aquifer, Texas. Barton Springs/Edwards Aquifer Conservation District unnumbered publication, Austin, Texas.

Ford D. 2004. Karst. In: Gunn J, editor. Encyclopedia of caves and karst science. New York (NY): Fitzroy Dearborn, p. 902.

Gunn J. 2004. Encyclopedia of caves and karst science. New York (NY): Fitzroy Dearborn.

Halihan T, Mace RE, Sharp JM Jr. 2000. Flow in the San Antonio segment of the Edwards Aquifer: matrix, fractures, or conduits? In: Wicks CM, Sasowsky ID, editors. Groundwater flow and contaminant transport in carbonate aquifers. Rotterdam (Netherlands): A.A. Balkema, p. 129-146.

Hauwert NM, Johns DA, Sansom JW, Aley TJ. 2002. Groundwater tracing of the Barton Springs Edwards Aquifer, Travis and Hays Counties, Texas. Gulf Coast Associations of Geological Societies Transactions 52. p. 377-384.

Hauwert NM, Johns DA, Sansom JW, Aley TJ. 2004. Groundwater tracing of the Barton Springs Edwards Aquifer, southern Travis and northern Hays Counties, Texas. Report by the Barton Springs/Edwards Aquifer Conservation District and the City of Austin Watershed Protection and Development Review Department.

Hauwert, N. 2009. Groundwater flow and recharge within the Barton Springs segment of the Edwards Aquifer, Southern Travis and Northern Hays Counties, Texas [Ph.D. dissertation]. Austin (TX): University of Texas at Austin, 328 p.

Hauwert N. 2011. Water budget of stream recharge sources to the Barton Springs segment of the Edwards Aquifer. World Lake Conference, Austin, Texas.

Hauwert N. 2012. Recharge to the Barton Springs segment of the Edwards Aquifer: Major creek channel and river contributions. City of Austin short report in preparation.
HBC/Terracon. 2005. Preliminary geotechnical study, The Shops at Arbor Trails, MoPac Expressway at William Cannon Drive, Austin, Texas. Report by $\mathrm{HBC} /$ Terracon Geotechnical Engineering Division. Austin (TX). Terracon Project No. 96045287.

HBC/Terracon. 2004. Geologic assessment: The Shops at Arbor Trails, MoPac at William Cannon Drive, Austin, Texas. Report by HBC/Terracon. Austin (TX).

Hovorka S, Mace R, Collins E. 1995. Regional distribution of permeability in the Edwards Aquifer. Gulf Coast Association of Geological Societies Transactions XLV. p. 259-265.

Hovorka S, Dutton A, Ruppel S, Yeh J. 1996. Edwards Aquifer ground-water resources: Geologic controls on porosity development in platform carbonates, South Texas. The University of Texas at Austin, Bureau of Economic Geology Report of Investigations 238 .

Hovorka S, Mace R, Collins E. 1998. Permeability structure of the Edwards Aquifer, South TexasImplications for aquifer management. The University of Texas at Austin, Bureau of Economic Geology Report of Investigations 250.

Hunt B, Smith B, Beery J, Hauwert N, Johns D. 2005. Structural influence on groundwater flow as evidenced by groundwater dye tracing in the Barton Springs segment of the Edwards Aquifer, Central Texas: Implications for Modeling Conduits. Geological Society of America. SouthCentral Meeting Abstracts with Programs 37 (3). San Antonio, Texas. April 1.

Johnson S, Schindel G, Veni G, Hauwert N, Hunt B, Smith B, Gary M. 2012. Tracing groundwater flowpaths in the vicinity of San Marcos Springs, Texas. Edwards Aquifer Authority Report 12-03. San Antonio (TX).

Kastning EH. 1987. Solution-subsidence-collapse in central Texas: Ordovician to Quaternary. In: Beck B, Wilson WL, editors. Karst Hydrogeology: Engineering and Environmental Applications, Proceedings 2nd Multidisciplinary Conference on Sinkholes and the Environmental Impacts of Karst. Orlando (FL). p. 41-45.

Kleinfelder. 2005. Phase I environmental assessment: Proposed Costco Wholesale Facility \#030108. Austin (TX).

Klimchouk A. 2007. Hypogene speleogenesis: Hydrogeological and morphogenetic perspective. National Cave and Karst Research Institute Special Paper 1. Carlsbad, New Mexico.

Lindgren R, Dutton A, Hovorka S, Worthington S, Painter S. 2004. Conceptualization and simulation of the Edwards Aquifer, San Antonio region, Texas. US Geological Survey Scientific Investigation Report 2004-5277. 
Maclay RW, Small TA. 1986. Carbonate geology and hydrogeology of the Edwards Aquifer in the San Antonio Area, Texas. Texas Water Development Board Report 296.

Newton JG, Tanner JM. 1987. Case histories of induced sinkholes in the eastern United States. In: Beck B, Wilson WL, editors. Karst Hydrogeology: Engineering and Environmental Applications, Proceedings 2nd Multidisciplinary Conference on Sinkholes and the Environmental Impacts of Karst. Orlando (FL). p. 15-23.

Schindel GM, Johnson SB, Alexander EC. 2008. Hypogene processes in the Balcones Fault Zone of the Edwards Aquifer in south-central Texas, a new conceptual model to explain aquifer dynamics. Geological Society of America Abstracts with Programs 40 (6): 342.

Sharp JM Jr. 1990. Stratigraphic, geomorphic and structural controls of the Edwards Aquifer, Texas: U.S.A.. In: Simpson ES, Sharp, JM Jr, editors. Selected Papers on Hydrogeology. Hannover (Germany): Heise. International Association of Hydrogeologists 1, p. 67-82.

Small TA, Hanson JA, Hauwert NM. 1996. Geologic framework and hydrogeologic characteristics of the Edwards Aquifer outcrop (Barton Springs segment), northeastern Hay sand southwestern Travis counties, Texas. US Geological Survey Water Resources Investigations Report 96-4306.

Slade R Jr, Dorsey M, Stewart, S. 1986. Hydrology and water quality of the Edwards Aquifer associated with Barton Springs in the Austin area, Texas. US Geological Survey Water-Resources Investigations, Report 86-4036.

Slade R Jr, Ruiz L, Slagle D. 1985. Simulation of the flow system of Barton Springs and associated Edwards Aquifer in the Austin Area, Texas. US Geological Survey Water-Resources Investigations Report 85-4299.

Todd DK, Mays LW. 2005. Groundwater hydrology. 3rd ed. New York (NY): John Wiley \& Sons, Inc.

White W. 1988. Geomorphology and hydrology of karst terrains. Oxford (England): Oxford University Press.

Williams P. 2004. Dolines. In: Gunn J, editor. Encyclopedia of caves and karst science. New York (NY): Fitzroy Dearborn, p. 305-310. 